\title{
Los poderes de la imagen: para una iconología social (esbozo de una autobiografía intelectual)!
}

\author{
Juan Antonio Ramírez \\ Universidad Autónoma de Madrid
}

Quiero, en primer lugar, agradeceros el honor que me habéis hecho al invitarme a participar en vuestro seminario de egohistoria. Creí entender que me proponíais hablar de lo que he hecho hasta ahora como historiador del arte y como persona comprometida con los asuntos culturales. Dado que conocía mis propios escritos y también las motivaciones de los mismos pensé que esta intervención no requería un esfuerzo especial. Pero en seguida me di cuenta de mi error. Tenía que reflexionar sobre múltiples cosas, hechas en momentos muy distintos de mi vida, y en un contexto sociopolítico de extraordinario dinamismo. $Y$ no se trataba de imitar el detestable ejercicio de las antiguas oposiciones consistente en convencer al tribunal de los grandes méritos del candidato a la plaza, sino de algo muy distinto: detectar el sentido histórico de la actividad intelectual, examinarla críticamente, identificando y contextualizando los posibles logros pero también los fracasos. Esta especie de psicoanálisis del trabajo ha de contar con el reconocimiento de que la mirada al pasado está llena de trampas y de coartadas, es parcial e interesada, maquilla los acontecimientos, omite unas cosas y magnifica otras. ¿Cómo objetivarme luchando contra la tendencia a la deformación y a la autocomplacencia? Es una ardua tarea, y no creo que pueda llevarla a cabo de un modo razonable sin la colaboración que espero de vosotros en el coloquio que seguirá a esta charla.

Mis dos primeros libros llevan la fecha de 1975: El cómic femenino en España. Arte sub y anulación (en formato de bolsillo) se publicó unos meses antes del fallecimiento de Francisco Franco; el segundo, La historieta cómica de postguerra (en cartoné y con ilustraciones en color) salió muy poco después de la muerte del dictador. Ambos fueron publicados EDICUSA, la misma editorial que lanzaba la revista Cuadernos par el Diálogo, una publicación importantísima para la aglutinación de la oposición antifranquista en los años finales de la dictadura. Recuerdo las largas sesiones de trabajo, maquetando el segundo de mis libros con Rafael Martínez Alés, en la sede de la editorial, mientras escuchábamos (ilusionados) por la radio los partes médicos emitidos durante la agonía del general. No es esto una mera anécdota, pues me parece ahora que mi vida intelectual empezó mediante un ajuste de cuen-

* RAMÍREZ, Juan Antonio: "Los poderes de la imagen: para una iconología social esbozo de una autobiografía intelectual", en Boletín de Arte, $n^{\circ}$ 29, Departamento de Historia del Arte, Universidad de Málaga, 2008 , págs. 509-537.

1 Texto de la intervención en el Seminario Vida y Cultura: Reflexiones Egohistóricas. Instituto de Historia, Centro de Ciencias Humanas y Sociales, CSIC, Madrid 19 de junio de 2008. 
Q: varia Juan Antonio Ramírez

tas con aquella España de Franco a la cual desdeñábamos profundamente. Mi rechazo era tan visceral que no supe distinguir bien entonces entre la dictadura propiamente dicha y los sectores de la ciencia y de la cultura que coexistían con el sistema político pero no formaban, en sentido estricto, parte de él.

Es necesario que me detenga en esto, pues explica, en parte, mi decisión de hacer una tesis doctoral sobre los tebeos (o cómics, como ya se decía entonces) en España entre el final de la guerra civil y principios de los años setenta. Creo que, investido de una arrogancia que hoy me parece sonrojante, yo alimentaba una doble intención: desmontar y desacreditar la ideología del nacional-catolicismo, omnipresente en aquellos cómics, y abofetear a lo que creía que era la "historia del arte oficial" de aquel momento, consagrada al estudio de las venerables obras custodiadas en los museos. Ambos propósitos estaban entremezclados. Cuando el profesor Diego Angulo, director entonces del Instituto Diego Velázquez del CSIC, intentó disuadirme de mi intención de estudiar los tebeos y me propuso, como (un buen) ejemplo, dedicar mis energías intelectuales a "un escultor bueno, castellano, del siglo $\mathrm{XVI}$ ", yo me reafirmé en mi propia decisión. Aquel consejo benevolente (y los de otros compañeros y amigos, en una línea parecida) emanaba, para mí, de la caverna apolillada de la dictadura. Nunca sabré si me equivoqué al elegir una ruptura tan radical con las orientaciones de mis antiguos profesores, pero sí está claro que el tema de la tesis determinó decisivamente mi futuro intelectual.

Y no me refiero ahora a los asuntos estratégicos relacionados con la promoción profesional, pues nadie preveía entonces que pudiera haber algún futuro en la universidad española (y menos aún en aquel Instituto Diego Velázquez del CSIC dominado por Diego Angulo) para alguien que se "suicidaba" eligiendo los cómics del franquismo como investigación doctoral. Pienso el algo más sutil: los tebeos me obligaron a cambiar la manera de entender todo el arte. Se trataba de una producción iconográfica gigantesca desde el punto de vista cuantitativo y eso solamente hacía inevitable el replanteamiento de algunas cuestiones que afectaban a otras producciones iconográficas del pasado. ¿Cómo han funcionado las imágenes en el seno de la vida social?

Los productos que yo estudiaba se habían dirigido a diversos segmentos del público y por eso mi tesis tuvo tres grandes apartados dedicados al tebeo de aventuras (para un consumo preferentemente masculino), al tebeo sentimental (femenino), y a los tebeos humorísticos (más adultos y de consumo familiar). Era evidente que tales grupos de tebeos se diferenciaban por la temática, por la apariencia y por el "estilo" de sus dibujantes, de modo que resultó muy interesante tener en cuenta la relación solidaria entre los lenguajes artísticos y distintos segmentos de consumidores. No hablo sólo de las clases sociales al estilo de Arnold Hauser (a quien había leído durante mis estudios universitarios) o de Frederick Antal, sino de otros subgrupos humanos. La importación de criterios analíticos procedentes de la sociología o de la economía la hice con naturalidad, casi inconscientemente. Bastó con cambiar el objeto de estudio para que surgiera la necesidad de alterar los métodos de trabajo. Así surgieron las cuestiones de género, que eran entonces desconocidas entre nuestros estudiosos. El cómic 
femenino en España fue también, en consecuencia, uno de los primeros estudios "feministas" de nuestra historia del arte. Y "masculinistas" fueron las consideraciones relativas al tebeo para chicos (publicadas, en lo sustancial, en tres largos artículos aparecidos en la Revista de Estudios Sociales). Tuve muy en cuenta lo que la ideología del nacional-catolicismo quería inculcar a la mujer, y al varón, como entelequias bien diferenciadas (géneros construidos, diríamos ahora), aportando de mi propia cosecha la búsqueda de una relación entre lenguajes visuales, momentos precisos en la historia del género, y niveles socioeconómicos (clase social) de los consumidores.

En los tebeos humorísticos creíamos detectar una visión crítica solapada de la sociedad del franquismo: nos proporcionaron una buena oportunidad para desplegar un método, inspirado en el psicoanálisis, que examinaba las formas y las estructuras narrativas como síntomas de enfermedades y traumas sociales. El analista cumplía una especie de tarea terapéutica desvelando el sentido escondido de aquellas creaciones. La verdad es que no éramos conscientes entonces de hasta qué punto proyectábamos sobre el objeto de estudio los hábitos culturales del solapamiento y el sobrentendido que nos había inculcado la represión intelectual del franquismo.

Con esta parte de mi tesis elaboré mi segundo libro, como ya he dicho antes. La editorial se había animado por el éxito de crítica del primero (al que concedieron el "Premio de Ensayo Ciudad de Barcelona" de 1975) y decidieron que La historieta cómica de postguerra fuese muy ilustrado, encuadernado en cartoné, y que llevara algunas láminas en color. Por eso fue necesario maquetarlo página a página. Aprendí entonces cómo se produce físicamente un libro ilustrado y tuve oportunidad de reflexionar por primera vez acerca de la relación inevitable ente lo que el lector "lee" y lo que "ve". Estaba bien preparado para aquella revelación, desde luego, pues el cómic es un medio icónico-verbal donde ninguno de sus dos componentes (literario y visual) puede vivir sin el otro, pero aún así tuvieron que pasar muchos años hasta que pude albergar con claridad la idea de que la historia del arte es la única disciplina humanística que se sirve de esas mismas estrategias: la ilustración forma parte del discurso. Sus modos de argumentar (basados desde la Antigüedad hasta el renacimiento en la ékfrasis, o pobremente apoyados en grabados de ejecución manual a partir del siglo $\mathrm{XVI}$ ) cambiaron radicalmente cuando el desarrollo de la fotografía permitió disponer de numerosos testimonios fiables de obras artísticas muy alejadas en el espacio y en el tiempo. Lo más importante es que el progreso en los procedimientos de reproducción fotomecánica permitió la aparición de libros y estudios histórico-artísticos cuya "forma" era similar al reportaje fotográfico o a la página de cómic.

No lo expresé de esta manera en mi tercer libro, Medios de masas e historia del arte (1976), pero sí sacaba en él las primeras consecuencias teóricas de mi trabajo en una parcela de la cultura visual de masas, abordando de frente una cuestión que preocuparía mucho, dos décadas después, a los teóricos anglosajones de los visual studies: ¿De qué modo se ve afectada la historia del arte por la inclusión en su seno del análisis de los nuevos medios? La primera parte del libro era una apresurada historia universal de las imágenes desde el punto de vista económico y cuantitativo, es 


Q: varia Juan Antonio Ramirez

decir, que me importaba describir el acelerado proceso de "densificación iconográfica" (esta expresión la acuñé entonces) que condujo de los primeros grabados en madera del siglo XV hasta el mundo de la imagen ubicua y masiva que detectaba en las sociedades contemporáneas. La segunda parte era una descripción de cada uno de los medios de masas, en tanto que lenguajes específicos (y de ahí la óptica semiológica adoptada, muy de moda en aquella época en otros campos de la crítica cultural, aunque no en la historia del arte). La última parte del libro, en fin, sí se ocupaba de esa subversión de la disciplina (que yo creía inminente) como consecuencia de la necesidad ineludible de dar cuenta de la producción artística de los medios de masas. Había bastante mesianismo "marxistoide" en mis argumentaciones, con un conjunto de silogismos entrelazados y de presuposiciones que quizá pueda resumir ahora de siguiente modo: el progreso industrial y la democratización creciente de la imagen conducen a (o coinciden con) la progresiva liberación de las masas; el arte único de las élites (la pintura y la escultura tradicionales) carece ya de la relevancia social que tuvo en el pasado; la historia del arte del futuro se ocupará de otros asuntos y no obviará los aspectos cuantitativos y económicos de la producción imaginaria. Pero no era tan sociologista como puede parecer, pues creo que tenía ya muy introyectada la idea de que el arte es un conjunto de lenguajes, y admitía de buena gana la idea de que posee unas estructuras (unas gramáticas) relativamente independientes de los avatares de la vida social. Creo que aquella posición se ha mantenido tácitamente estable, es decir, que sigo defendiendo la posibilidad (o la necesidad) de hacer una verdadera historia social del arte a partir del análisis de las creaciones concretas, sin negar la especificidad de la creación y la dinámica propia de los lenguajes visuales.

La redacción de aquel librito me dejó exhausto, pero también feliz, como cuando uno presiente que ha podido culminar un ciclo, o alcanzado alguna meta. No era muy consciente de que la pasión que había puesto al escribirlo no garantizaba la calidad del resultado. Supongo que me bastaba con haberme demostrado a mi mismo que había otros caminos además de estudiar el hipotético "escultor bueno, castellano, del siglo XVI". También estaba muy orgulloso de que mi libro fuera el primero de arte que la Editorial Cátedra sacaba bajo la dirección de mi maestro Antonio Bonet Correa. Debo hacer un inciso aquí para mencionar el papel que esta personalidad jugó en mi vida intelectual: él había aceptado, recién llegado desde Sevilla a la Universidad Complutense de Madrid, dirigir mi tesis doctoral, percibiendo con sagacidad la pertinencia de los asuntos que pretendía suscitar. Le atrajo la novedad del tema y del planteamiento, y también apreció el apoyo que me prestó Simón Marchán Fiz, que había dirigido antes mi tesina de licenciatura, dedicada a Las historietas de la Escuela Bruguera. Antonio Bonet (antiguo profesor mío en los cursos "comunes" de Filosofía y Letras en la Universidad de Murcia) no interfirió apenas en mi trabajo pero sí me dio, en una primera fase, un excelente consejo: que no pagara demasiado tributo a las modas epistemológicas del momento y que hiciera un trabajo más general del que pretendía inicialmente ( Yo había abrigado la delirante fantasía de que mi tesis fuese un análisis semiótico muy minucioso de una sola página de cómic!). Quizá él no fuera 
Q Varia Los poderes de la imagen: para una iconología social...

consciente de ello pero me estimuló para que mi trabajo estuviese más cerca de la historia que de la crítica. Y luego me encargó, para Cátedra, un libro sobre los nuevos medios, que es el que acabo de comentar, de indudable vocación generalista. Pero entrar en la órbita de Antonio Bonet Correa supuso muchas cosas más: empecé a dar clases de historia del arte, primero en el Centro Universitario de Toledo y luego en la Facultad de Geografía e Historia de la Universidad Complutense, donde me encargaron cursos de Arte del Barroco, entre otras materias. Tuve que estudiar intensamente cosas muy variadas, y es entonces cuando creo que empecé a aprender de verdad historia del arte y de la arquitectura, aunque no sentí como un estorbo el bagaje que me habían aportado mis trabajos sobre el arte y la cultura de masas sino todo lo contrario, como trataré de explicar luego. El caso es que me socialicé como universitario en la cátedra de Antonio Bonet; también en el "salón" (por decirlo de alguna manera) de su casa, que era lo más moderno e internacional que se podía encontrar en aquel Madrid de la segunda mitad de los años setenta.

Muchas cosas estaban cambiando en España, y muy aceleradamente. En junio de 1977 se produjeron las primeras elecciones democráticas. Yo pegué carteles del PCE durante la campaña electoral, y participé como interventor de ese partido en la mesa electoral de un barrio periférico de Madrid. Pero el resultado fue decepcionante: quedó claro que la hegemonía de la izquierda sería en lo sucesivo para los socialistas, que se aprestaban, a su vez, a abandonar el marxismo como sustento ideológico. A finales de 1978 se aprobó la Constitución. Yo superé por entonces las oposiciones a Profesor Adjunto de Historia del Arte en la Universidad Complutense y me embarqué en una larga investigación pensando en escribir un libro que iba a titular "EI Templo de Salomón como sueño arquitectónico". ¿Cómo fue posible ese cambio de tercio, aparentemente tan radical? Tengo muchas explicaciones y no sé si alguna de ellas es la verdadera: estaba orientándome hacia la historia de la arquitectura (y así lo muestra un librito de transición como es El perfil de una utopía: la catedral nueva de Orihuela); es cierto que soñé con el Templo varias veces, y que ese edificio aparecía siempre con una forma diferente; también puede que quisiera decir a mis colegas que no quería seguir siendo etiquetado peyorativamente como "ése de los cómics". Pero no descarto que los acontecimientos históricos estuvieran inundando algunas capas freáticas del inconsciente: la imposibilidad de materializar nuestro viejo anhelo político, o la percepción, quizá, de que aquella utopía era simplemente descabellada, pudo haberme llevado a seguir trabajando en ella, transformada ya en fantasía o ensoñación arquitectónica. Mi marxismo se aproximaba al de un Ernst Bloch que considera a la creación artística como una parte esencial de la actividad utopizante. Yo quería progresar, en cualquier caso, y no me apetecía limitarme a administrar la parcelita intelectual que había acotado con mis primeros libros. Lo mejor era mudar radicalmente de orientación y desaparecer de la escena cultural durante algún tiempo. Creo que eso me dejó un hábito que he practicado sistemáticamente desde entonces, huyendo siempre del tema que acababa de estudiar, una vez aclarados los enigmas esenciales que me habían movido a investigarlo. 


\section{Q: varia Juan Antonio Ramirez}

En aquella ocasión lo hice marchándome al Warburg Institute de Londres donde pasé todo el curso académico 1979-80, con una beca postdoctoral. Fue un año decisivo: viví allí la ascensión al poder de Margaret Thatcher, y tuve la oportunidad de conocer a Anthony Blunt en los momentos más aciagos de su vida cuando, tras haberse hecho pública su antigua actividad como espía al servicio de la Unión Soviética, fue despojado de sus honores y convertido en una especie de paria al que negaron la palabra muchos de sus viejos amigos. Me lo presentó Jennifer Montagu, responsable entonces de la colección fotográfica del Warburg (debió percibir mi escaso aprecio por la histeria que se había desatado en torno a su maestro), y de ella me vino una invitación para compartir con Blunt el palco durante una representación de La flauta mágica de Mozart. Nada me parece ahora casual: yo y otro invitado extranjero cuyo nombre he olvidado, desconocidos absoluto del público londinense, fuimos colocados en la parte delantera, y Anthony Blunt asistió a la ópera desde la penumbra del segundo plano. No se me escapan tampoco las implicaciones masónicas y liberales de aquella ópera. Allí mantuvimos, durante el descanso, una conversación aparentemente neutral, sobre el barroco napolitano y el español, muy ajenos entre sí, según la opinión de Blunt. Pero la tensión se palpaba en el ambiente, y creo que todos estábamos algo preocupados por algunos cuchicheos y miradas de reojo. ¿Ejercí aquella noche, sin saberlo, de improvisado guardaespaldas?

Mis conversaciones en el Warburg (con Blunt y con otros estudiosos de distintos países, como John Onions, Héctor Ciocchini, o Robert Jan van Pelt) reflejaban mis dudas intelectuales. El Templo aparecía como un asunto de "tiempo largo" (en el sentido que da a este término Fernand Braudel), difícil de encajar en el tipo de historia social del arte que me había interesado hasta entonces. Era una constante del pensamiento arquitectónico cristiano pero no parecía imposible examinar su desarrollo siguiendo los ritmos (estilos y periodos) trazados por la historia del arte ordinaria. La iconografía del Templo me obligó a reparar en la autonomía de algunos ingredientes formales, que parecían perforar los siglos, y que eran aparentemente inmunes a las transformaciones de las sociedades. ¿Tenían las imágenes también una vida inconsciente, una lógica secreta? ¿No permitía esto resucitar una vez más algunos conceptos lingüísticos? Me refiero ahora al hecho, mencionado antes, de la independencia de las lenguas respecto a los cambios sociales. El caso es que durante una época me causó inquietud el darme cuenta de que no sabía qué hacer con los métodos de inspiración marxista y semiótica que me habían servido hasta entonces. El ostracismo londinense de Blunt y la marea conservadora de mi entorno (en España gobernaba la UCD y en el Reino Unido se iniciaba el largo imperio de la "dama de hierro") anunciaban la quiebra de un universo referencial cuyo derrumbamiento culminaría, una década después, con la caída del muro de Berlín. Lo más evidente en aquellos momentos es que la dictadura había sido sustituida por un régimen democrático, y que eso había hecho desaparecer repentinamente la simple militancia "antifranquista".

Si el ideal comunista parecía no tener futuro, y ya no era necesario luchar por las libertades, podíamos dedicarnos sin remordimientos a cuestiones como la teoría o 
Q Varia Los poderes de la imagen: para una iconología social...

la iconografía de la arquitectura, poniendo entre paréntesis muchos viejos asuntos políticos y sociales. Yo regresé de Londres a Madrid para presentarme a la oposición de unas agregadurías, que había firmado hacía tiempo, y quiso la buena fortuna que sacara la plaza el veinticuatro de junio, día de mi cumpleaños. Le pedí a mi amigo Ignacio Henares (el otro candidato que aprobó conmigo) que comprendiera mi deseo de elegir la vacante de Málaga, que era la ciudad donde yo había nacido treinta y dos años antes, y donde no había vuelto a residir desde que tenía unos meses de edad: aunque no me interesaba en serio todavía por el surrealismo, ya pagaba tributo al "azar objetivo" dando por supuesto que un designio secreto me devolvía al lugar de mi origen. Llegué a Málaga sobresaturado de energía e ilusiones. En su universidad me recibieron de un modo maravilloso y yo pasé allí los mejores años de mi vida académica. Además de las múltiples actividades docentes y sociales en las que me involucré, dediqué muchas horas a estructurar lo que venía rumiando desde hacía unos años, y así es como pude publicar en 1983 dos libros, estrechamente interconectados: Edificios y sueños (Ensayos sobre arquitectura y utopía)y Construcciones ilusorias. Arquitecturas descritas, arquitectura pintadas. Aparecieron ya durante mi segundo año en Málaga, después de un interludio en la Universidad de Salamanca (a donde me trasladé como catedrático el curso 1981-82) y en la Columbia University de Nueva York (donde estuve como "visiting scholar" el curso 1982-83). Aprovechaba en esos volúmenes muchos de los materiales acumulados en Londres, insertando la problemática del Templo en un contexto más amplio de fantasías, evocaciones, e imágenes arquitectónicas. Pero el acento de cada uno de estos libros era diferente: las arquitecturas que no existen, en un caso, entendidas como utopías (hablaba del sistema de los órdenes arquitectónicos, de algunas réplicas medievales del Tempo como edificio centralizado, de la iglesia romana de San Ivo alla Sapienza, y de otros asuntos más contemporáneos que luego comentaré); y de la relación entre los textos y las visualizaciones arquitectónicas, en Construcciones ilusorias. Había en este libro un capítulo dedicado a la arquitectura en la pintura del renacimiento y otro, bastante largo, titulado "Arquitectura y lugar imaginario (El Templo de Jerusalén en la pintura antigua)" que me sirvieron para mostrar las posibilidades de una nueva rama de la disciplina que llamé la iconografía del lugar. Me pareció que en las representaciones antiguas del Templo había un interesante ámbito de confluencias entre los textos, las tradiciones visuales y los conocimientos históricos precisos. La iconografía se había venido ocupando de los personajes y de la acciones, pero muy poco de los lugares donde se sitúan las escenas, y yo intenté decir que era posible examinarlos de un modo sistemático. Algunos colegas se han quedado con el término y lo han utilizado ocasionalmente, olvidando su origen, pero aún así no parece que, un cuarto de siglo después, se haya desarrollado mucho más esa rama del saber.

Debo preguntarme ahora por qué mi propuesta de desarrollar a fondo una "iconografía del lugar" parece haber caído en el vacío. Creo que fue planteada en un lugar y en un momento inadecuados. A principios de los años ochenta algunos asuntos generales dejaron de ser acuciantes para los historiadores del arte españoles porque 


Q: varia Juan Antonio Ramírez

el recién fundado estado de las autonomías estimuló una reorientación de la disciplina hacia la tarea de la re-construcción de las identidades nacionales y regionales. Hubo demasiado trabajo conectado con esos ámbitos (exposiciones con gran cobertura mediática, publicaciones subvencionadas, cargos públicos, etc.), y muy pocos estímulos para investigar en otros dominios. En ese contexto mis libros fueron seguramente excéntricos, en todos los sentidos de la palabra, y quizá debiera haberlos publicado en otro país. Pero el interés de una editorial norteamericana por sacarlos en inglés chocó con una dificultad inesperada: no teníamos los derechos de reproducción de las imágenes, no supe cómo resolver el problema, y dejé morir de indiferencia ese proyecto, acuciado como estaba por otras preocupaciones más estimulantes que la mera gestión burocrática de algo que yo daba por concluido. No quiero extenderme aquí sobre las lecciones que debería extraer de éste y de otros casos similares (como el de Corpus solus, otro libro mío que tampoco fue publicado en inglés por el maldito escollo de los derechos de las ilustraciones) pero sí debo decir que fui consciente de las consecuencias de mi elección al reafirmarme en una postura que he mantenido hasta ahora: trabajar en lo que me interesa y publicarlo como quien lanza botellas al mar, con la esperanza de que alguien, en algún momento, pueda sintonizar con los mensajes que intento transmitir. No me preocupo mucho, en fin, de la recepción de mis trabajos, pues acepto de buena gana que los discursos científicos pueden ser algo minoritario, que muy pocos son capaces de comprender. Este relativo desapego de la vida pública de mis escritos es un error, sin duda, pero no puedo cambiar de país, ni de idioma, ni darme la vuelta a mi mismo. Me consuelo suponiendo que los malentendidos (o desentendidos) intelectuales que generan mis trabajos pueden tener un valor creativo, y son de la misma naturaleza que los originados por mí mismo cuando malinterpreto, también (sin querer o queriendo), el sentido de lo que hacen los demás.

El último capítulo de Edificios y sueños estaba dedicado a la arquitectura en los cómics y en el cine, dos medios secuenciales cuyos "lugares imaginarios" me parecían especialmente fascinantes. Pero las consideraciones que hacía allí eran insuficientes y sentí la necesidad de colocar un zoom analítico sobre el tema. Trabajé sistemáticamente sobre ese aspecto, durante unos años, y muy especialmente en el curso 1982-83, beneficiándome de los fondos maravillosos de algunas bibliotecas y centros de investigación de Nueva York. El resultado fue La arquitectura en el cine. Hollywood, la Edad de Oro (1986). Era una aportación a la historia del cine (no abandonaba, según parece, mi viejo interés por la cultura visual de masas), pero yo lo veía más como un trabajo de historia de la arquitectura en el cual se contaba la victoria épica del Movimiento Moderno (culminada, en Hollywood, a finales de los años cuarenta) sobre la tradición ecléctica. Los decorados de cine eran edificios desinhibidos y simulados que sintonizaban muy bien con las corrientes de la arquitectura postmoderna, triunfantes por doquier cuando yo escribí aquel libro. Quizá por eso el tema se puso de moda poco después, favoreciendo la pervivencia de mi trabajo que ha sido reeditado varias veces y publicado en inglés por una editorial norteamericana.

Con La arquitectura en el cine quise responder a varios interrogantes: cómo se 
Q Varia Los poderes de la imagen: para una iconología social...

habían construido los lugares imaginarios en la mayor fábrica de arte (los estudios de Hollywood) que ha conocido la humanidad; de qué modo funcionan esos espacios codificados en la lógica de los relatos visuales; a qué motivaciones psicológicas han atendido; qué relación guardan con la historia de la arquitectura y cómo se insertaron en los debates estéticos coetáneos, etc. Pude construir un discurso icónico-verbal intercalando en el texto más de trescientas fotografías comentadas, gracias a la comprensión benevolente de Luis Fernández Galiano, que dirigía entonces la colección donde se publicó el libro por primera vez (aunque en la edición norteamericana se redujeron a la mitad debido, entre otras cosas, a los eternos temores originados por los "derechos de reproducción"). La maquetación de sus páginas, con una columna ancha para la caja del texto principal y otra estrecha, era muy flexible y elegante, y se prestaba bien a la necesidad de colocar las imágenes cerca del lugar donde se aludía a ellas. Adoptamos este mismo diseño luego para la reedición que hizo la editorial Nerea de Edificios y sueños y para otros libros míos publicados por Siruela en los años noventa. No era ése un asunto menor para mí, pues tenía ya clara consciencia de que la forma puede ser una parte importante del discurso de la historia del arte: siempre me ha parecido importante convencer a los editores de que las ilustraciones no son un elemento aleatorio del que puede disponerse caprichosamente.

Encontré un cómplice excepcional para estas preocupaciones en Jacobo Stuart, el joven aristócrata que había fundado, a principios de los años ochenta, Ediciones Siruela. Me invitó a dar una conferencia en un curso inolvidable de la Universidad Menéndez Pelayo, en Sevilla (al que asistieron, entre otros ponentes, Borges, Italo Calvino y Torrente Ballester), por las mismas fechas en las que se produjo el entierro apoteósico del torero Paquirri, y no perdimos ya el contacto en los tres lustros siguientes. Al poco de conocernos Jacobo me preguntó qué podíamos hacer y como yo le viera inclinado hacia lo inusual, le propuse traducir y publicar la reconstrucción monumental del Templo de Salomón de Juan Bautista Villalpando. Fuimos a ver juntos el ejemplar de la Biblioteca Nacional. Para gran sorpresa mía, se entusiasmó con el proyecto, y así es como empezó una aventura intelectual que duró siete años y que culminó en 1992 con la publicación de la primera traducción completa en castellano del volumen segundo de Villalpando, de la edición facsímil de todos los grabados de los tres tomos, y del manuscrito alternativo sobre el Templo, de Jerónimo de Prado, que se conserva en Harvard. Recabé la colaboración de un selecto equipo internacional con el que elaboramos el volumen complementario de estudios titulado Dios, arquitecto. Aunque yo fui el animador, el trabajo más duro, verdaderamente hercúleo, estuvo a cargo del traductor del latín, José Luis Oliver Domingo, y del propio Jacobo Stuart, que no escatimó esfuerzos para ofrecer un producto muy exquisito (justamente recompensado luego con varios premios de edición).

Así es como se materializó (y se superó) mi vieja idea de hacer un libro sobre el Templo. Conseguí culminar el proyecto gracias a la inercia de mis investigaciones anteriores (especialmente las que había hecho en el Warburg Institute), pues durante la 


Q: varia Juan Antonio Ramirez

segunda mitad de los años ochenta estaba ya más interesado por diversos asuntos del arte y la arquitectura del siglo XX. Pero el relativo desapego respecto al tema de Villalpando tuvo, paradójicamente, algunos efectos beneficiosos. Me hizo aceptar con mayor humildad, por ejemplo, la conveniencia de recabar la colaboración de otros estudiosos. ¿Habría sido Dios, arquitecto un libro colectivo de no haber estado yo entonces más inclinado hacia el arte contemporáneo? En cualquier caso pienso que, trabajando en solitario, no habría hecho mejor semejante libro, por mucho entusiasmo que hubiera puesto en la tarea. Actué como editor en el sentido anglosajón, acotando y asignando los temas y la extensión de cada parte, corrigiendo algunos detalles, etc. Tuve que aprender a respetar a los demás autores, algo no tan fácil cuando éstos se ocupan de asuntos sobre los que uno puede tener puntos de vista definidos y eventualmente discrepantes.

Intenté tapar los agujeros que los demás no cubrían, pensando en que la obra tuviera coherencia, y en que no fuera sólo una mera introducción a Villalpado. El Templo fue presentado en una doble perspectiva: como un tema especialmente importante de la iconografía cristiana, y como un problema "científico" afectado tanto por los estudios teológicos como por la arqueología del próximo oriente. Teníamos ya muy asumida esa "iconología de las connotaciones", que habíamos desarrollado con anterioridad, y que tanto nos estaba sirviendo en nuestros estudios de arte contemporáneo. Entendíamos por eso el estudio de los significados implícitos de las imágenes, de los vagos sentidos adheridos, y no sólo de lo que explícitamente vincula a las formas con los textos canónicos. Ni que decir tiene que esta perspectiva epistemológica permitía conectar con naturalidad el universo de la imagen con la ideología: no se perdía el contacto entre arte y sociedad. Puse mucho empeño en uno de los ensayos del libro donde se relacionaba la financiación de la empresa editorial de Villalpando con las consideraciones del padre Sigüenza sobre el coste económico del Monasterio de El Escorial. La idea de que Felipe II habría sido mejor rey (más prudente administrador) que Salomón tenía una fuerte carga política, demostrándose que las consideraciones relativas al Templo podían funcionar muy bien también en el seno de la historia social.

Pero toda aquella relectura de la problemática del Templo (la primera, como ya he dicho, fue la de los dos libros de 1983) estuvo muy condicionada por mi contacto con algunos episodios de las vanguardias históricas. El capítulo final de Edificios y sueños había estado dedicado a la arquitectura surrealista, y este asunto continuaba fascinándome casi una década después. El Templo de Salomón fue situado, en consecuencia, en la óptica de lo delirante. Me divertía mucho constatar que las más sesudas elucubraciones científicas sólo hubieran podido salvarse, a la postre, como ejemplos inspirados de la imaginación humana. El anhelo por lo desmesurado enlazaba a reconstructores del Templo como Villalpando o Lamy con el "delirio objetivo" de Salvador Dalí.

Por esos derroteros estaba, en efecto, durante la segunda mitad de los años ochenta. El curso 1984-85 me trasladé a la Universidad Autónoma de Madrid (donde he permanecido hasta ahora) y ahí me he venido encargando preferentemente de asignaturas relacionadas con el arte contemporáneo. Eso ha condicionado la temática de mis investigaciones ulteriores, que han oscilado entre la problemática artística y arquitectó- 
nica de las vanguardias históricas, y el análisis crítico de las creaciones de las últimas décadas del siglo XX. Dos estancias largas en el extranjero me ayudaron a profundizar en los asuntos que me interesaban: el curso 1988-89 lo pasé en París, y el 1991-92 acepté la invitación del Getty Center for the History of Art and the Humanities para investigar durante un año en su sede de Santa Mónica, en Los Ángeles.

En la capital francesa estudié a Salvador Dalí y recogí muchos materiales para un libro que habría de titularse, según fantaseaba entonces, "Metáforas del Movimiento Moderno". El proyecto se sustentaba en la convicción de que la nueva arquitectura del siglo XX había surgido encadenada a una serie de metáforas formales y funcionales que podían agruparse en cuatro grandes familias: mecánicas, minerales, biológicas y apícolas. Me entretuve mucho en estas últimas durante aquel año del centenario de la Revolución Francesa, y pienso que lo hice por varios motivos: quería regresar una vez más a las utopías, y el mundo de la colmena resultó un buen hilo conductor para transitar por algunos de los más hermosos anhelos de la modernidad; pero mi padre Lucio Ramírez, apicultor de profesión, acababa de fallecer, y creo que estudiar la influencia de la colmena en el arte y en la arquitectura del siglo $X X$, era mi manera de rendirle un homenaje. El tema, sin embargo, se quedó dormido y tardé casi una década en escribir y publicar el libro La metáfora de la colmena. De Gaudí a Le Corbusier. Ignoro el por qué de ese retraso, y no descarto que un sicoanálisis somero pudiera descubrir en ello razones autobiográficas complejas. En el prólogo hablaba de cómo, observando un día las colmenas de mi padre, descubrí de repente la conexión entre apicultura y arquitectura moderna, pero pedía disculpas a mis lectores por introducir recuerdos personales en un discurso académico.

Yo hablaba sutilmente también de la presencia en nuestras vidas de la Historia (con mayúscula): Lucio Ramírez había aprendido apicultura estando preso durante la guerra civil, y su visión de la "colmena humana" era el resultado (es decir, el refugio) del gran desbarajuste provocado por las revoluciones abortadas y por el triunfo del franquismo. El caso es que la colmena había sido a lo largo de la historia un referente ideológico ambivalente, adaptable a ideologías contrapuestas: sirvió para justificar tanto la vieja monarquía absoluta como la república igualitaria de la Revolución Francesa; el anarquismo y el socialismo, pero también la doctrina fascista del Lebensraum. Yo estaba fascinado por el descubrimiento de que muchos genios del Movimiento Moderno se hubieran servido de las metáforas apícolas. Profundicé más en los casos de Gaudí y de Le Corbusier, pero por las páginas de aquel librito desfilaron figuras tan significativas como Wright, Bruno Taut, Mies van der Rohe, Dalí, Beuys, Rudolf Steiner, etc. Se trataba de un formidable desafío intelectual pues estaba obligado a examinar los casos concretos para ver cómo un mismo referente podía funcionar política y estéticamente de modos completamente diferentes, según las circunstancias. La vieja "teoría del reflejo", más o menos marxistoide, se había hecho añicos, obviamente, pero también se tambaleaba la suposición freudiana (y jungiana) de que había símbolos visuales permanentes, de valor universal.

Ese libro fue, tal vez, demasiado breve y no explicité lo suficiente las implica- 


Q: varia Juan Antonio Ramírez

ciones teóricas de mis hallazgos. Intenté remediarlo, en parte, añadiendo algunas cosas más en la edición inglesa (que se han incorporado también a las traducciones a otros idiomas como el italiano, el rumano o el turco), pero no alteré sustancialmente la versión española original. El caso es que La metáfora de la colmena, gracias a sus traducciones, ha sido citado y discutido ampliamente. Se da así la paradoja de que un trabajo que parecen haber leído muy pocos colegas de mi propio país, sirve para identificarme, más que ningún otro, entre la comunidad académica internacional.

De finales de los años ochenta y de los primeros años noventa proceden las ideas y el trabajo básico del que salieron mis libros sobre Salvador Dalí y Marcel Duchamp. Sobre el artista catalán publiqué primero un largo ensayo en la revista $L a$ Balsa de la Medusa, resultado de mis muchas horas de trabajo en París, y del curso de verano que le dedicamos en la Universidad Hispanoamericana de La Rábida en 1989. Por aquellas fechas estudié con cierta intensidad la obra de Duchamp e impartí sobre él el curso de doctorado en el Museo Reina Sofía que se organizó conjuntamente entre las tres universidades madrileñas. Cuando llegué al Getty Center decidí que escribiría un ensayo sobre el inventor de los ready-mades, relativamente breve que, unido al que ya había hecho sobre Dalí, me permitiría ofrecer un libro bipartito (Duchamp-Dalí: el cristal y lo podrido, podría haberse titulado). Pero Duchamp me desbordó en seguida y supe, al cabo de unos días, que le estaba dedicando una obra independiente.

Nunca he trabajado en mejores condiciones que las de aquel año 1991-92 en el Getty Center donde tuve a mi alcance lo que sueña cualquier investigador: un entorno intelectual estimulante, materiales, bibliografía, y las horas completas de todos los días, muy lejos de las mil obligaciones que impone la vida académica en tu propio país. Mi libro sobre Duchamp me exigió, sin embargo, un esfuerzo enorme, y una gran determinación, también, para afrontar las incertidumbres que generaba el saber que muchas de mis opiniones y descubrimientos no concordaban con las de otros eminentes especialistas. Me sentía como una especie de paracaidista que había aterrizado en la terra incognita de la vanguardia procedente de territorios como ¡el Templo de Salomón! Pero aunque quizá fuese un advenedizo, también, por eso mismo, mi mirada carecía de ciertos prejuicios, y pude dar una visión "materialista" de Duchamp, despojándolo de las adherencias pseudo místicas que le había endilgado arbitrariamente la crítica de la generación anterior. Mi vieja formación en la cultura de la imagen y el bagaje adquirido con la "iconología de las connotaciones", me ayudaron mucho. También le debo algo a mi afición al bricolaje y al hecho de que yo había cursado un bachillerato técnico en el Instituto Laboral de Orihuela. Leí minuciosamente las notas de Duchamp y despiecé el Gran vidrio como si éste fuese un máquina, o varias, pues descubrí que en el panel inferior (el de los solteros) hay dos mecanismos independientes, de funcionamiento plausible. Rebusqué las fuentes iconográficas en los viejos manuales escolares, en los libros de mecánica y de electricidad, en los catálogos industriales de la época, etc.

Me sorprendió que no se hubiera hecho antes casi nada de eso, y llegué a la conclusión de que la formación filosófica y humanística de los especialistas en 
Q Varia Los poderes de la imagen: para una iconología social...

Duchamp, en todos los continentes, podía haber sido un obstáculo que les impedía reconocer una de las más fructíferas vías de acceso al objeto de sus estudios. Pero respeto las razones de quienes más se escandalizaron con mi libro. Algunos colegas españoles parece que se preguntaron: ¿Dónde anda éste, en los cómics, en la arquitectura cinematográfica, o en el Templo de Salomón? ¿Qué hace ahora escribiendo sobre Duchamp? Para colmo organicé mi relato de un modo bastante inusual, empezando con la crisis por la que pasó el artista en 1912, y sólo al final, como un apéndice, hablé del primer Duchamp, ese pintor que no habría pasado a la gran historia del arte de no haber emprendido luego aventuras como las de los ready-mades y el Gran Vidrio.

Sigo defendiendo lo sustancial de aquel libro, y sería hipócrita si fingiera una humilde ( $\mathrm{y}$ falsa) aceptación de algunas de las críticas recibidas. Yo "leí" el gran vidrio por estratos cronológicos, aplicando un método que había ensayado antes al descifrar la iglesia romana de San Ivo alla Sapienza (es, como ya he dicho, uno de los capítulos de Edificios y sueños). No me retracto de ello sino todo lo contrario, pues lo he vuelto a emplear más recientemente en mi nueva interpretación de los ready-mades (se encuentra en el prólogo a una obra popular sobre Duchamp y también en mi último libro, todavía inédito cuando escribo esto, titulado El objeto y el aura). Yo creo que, aunque contenía muchas cosas más, mi ensayo sobre Duchamp fue básicamente un ejercicio de iconografía del arte contemporáneo. Intenté contextualizar culturalmente las aportaciones de cada momento distinguiendo en el Gran Vidrio una etapa protodadaísta, otra dadaísta y una tercera presidida por el "azar objetivo" de los surrealistas. Ahora pienso en otra fase, próxima al pop art, cuando Duchamp dio su conformidad a las copias hechas por Hamilton y Ulf Linde, pero no desarrollé esta idea en mi texto de 1991-92, y sólo he hablado de ello, recientemente, en mis clases y en algunas conferencias.

Duchamp. El amor y la muerte, incluso fue publicado en inglés por una prestigiosa editorial londinense, y eso ha favorecido su circulación internacional. Pero tuvo también una excelente acogida en España, donde se han hecho varias reediciones hasta el momento actual. Lo han leído muchos artistas y también toda una nueva generación de historiadores del arte, dedicados ya al arte contemporáneo, una subespecie de la disciplina que no existía cuando yo empecé mi actividad académica. Es importante tener en cuenta que la escena artística española empezó a cambiar de modo radical a principios de los años noventa: el hedonismo posmoderno y el apoyo a la pintura (triunfante en los años ochenta) dio paso a una reemergencia de las corrientes conceptuales, a feminismos varios, a la explosión de nuevos procedimientos (fotografía de grandes formatos, video arte, instalaciones...) y a diversas formas de arte político. Duchamp, el artista "anti-retiniano", apareció como el padre y el profeta legitimador de muchos de aquellos nuevos desarrollos. Creo, pues, que mi libro se benefició de ese nuevo clima que se estaba fraguando en el llamado "sistema del arte contemporáneo", que surgía en nuestro país por primera vez. Yo lo describí en otro librito de aquellos años titulado Ecosistema y explosión de las artes. En la edición francesa le cambiaron el título pero la expresión "ecosistema del arte" ha hecho 
Q: varia Juan Antonio Ramírez

tanta fortuna que es ahora del dominio común y pocos saben dónde se originó.

El libro Dalí, lo crudo y lo podrido lo fui elaborando sin darme cuenta. Descubrí un día que estaba hecho cuando vi que podía agregarle al ensayo de La Balsa de la Medusa, ya mencionado antes, otros dos textos dedicados a las arquitecturas de Dalí y a las relaciones entre el método paranoico-crítico y el iconológico de WarburgPanofsky. La primera vez que formulé esa conexión, en uno de los congresos del CEHA, hubo quien pensó que yo estaba bromeando, pero aunque aprecio mucho el valor intelectual y moral del humor, hablaba en serio en aquella ocasión. Se trataba de tomar en consideración el motor inconsciente de la creación intelectual, algo que puede ser muy relevante en un seminario como éste en el que intentamos detectar las conexiones entre el trabajo individual y las pulsiones colectivas de la historia. ¿Hasta qué punto es paranoica la intuición que nos lleva a un descubrimiento inesperado? Creo que ofrecí algunas respuestas prácticas, ante casos concretos, en el libro de Dalí del que estoy hablando ahora, y también en La metáfora de la colmena. Lo más inquietante es la dificultad de distinguir entre esa paranoia "positiva" que nos permite encontrar directamente una verdad ocultada, y la "negativa" que nos conduce al error, o nos impulsa a mantenernos en él con temeraria obcecación.

Los libros que acabo de mencionar aparecieron ya durante unos años en los que me involucré bastante en la escena del arte contemporáneo. No he sido un crítico militante, de los que escriben en los medios sobre las noticias artísticas del día, pero sí me he aventurado al análisis y valoración de fenómenos y tendencias. Me ha gustado hacer artículos de extensión intermedia, sobre cosas de cierta relevancia, que pudieran ser leídos aunque el acontecimiento que los motivara hubiera ya dejado de ser noticia. Encontré la complicidad para practicar ese género en algunas revistas como Lápiz, o en los suplementos culturales de periódicos como El País o El Mundo. No me detendré en otras actividades relacionadas con todo esto, como mi etapa de columnista en los primeros números de Exit Express, o la más prolongada en Descubrir el arte. Pero sí quiero mencionar de modo especial la continuada hospitalidad de Arquitectura Viva, dirigida por un amigo sensible y receptivo a mis propuestas como es Luis Fernández Galiano. En sus páginas he escrito bastante de arquitectura y sobre todo de arte contemporáneo, para un público de arquitectos, fundamentalmente (aunque sin pensar en ellos de modo especial), y dando por descontado que algunos ecos de lo que dijera allí llegarían al sector artístico. Esto me ha llevado a ser, también, una especie de crítico de arte con sordina, una cómoda posición que me permite estar dentro y fuera de ese mundillo, al mismo tiempo. Quisiera creer que he mantenido mi independencia: el ser un desconocido para muchos galeristas, gestores y artistas me ha evitado sufrir las presiones padecidas por quienes se hallan en la primera línea de esa profesión.

En realidad la crítica, tal como yo la entiendo, es una parcela de la actividad didáctica, y ésta, a su vez, una subdelegación del trabajo científico propiamente dicho. Supongo que estoy tratando de decir que no veo discontinuidad ni contradicción en una cadena de actividades estrechamente conectadas entre sí como son la enseñanza, la 
Q Varia Los poderes de la imagen: para una iconología social...

elaboración de manuales docentes (a distintos niveles), el asesoramiento editorial, la escritura en revistas semiespecializadas, y la redacción de textos científicos dirigidos a un público académico. Nuestra misión es reelaborar y crear el conocimiento. Pero no hay un solo lugar para hacerlo, y por eso mi libro Cómo escribir sobre arte y arquitectura tenía este subtítulo: "Libro de estilo e introducción a los géneros de la crítica y de la historia del arte". Lo hice para ayudar a los estudiantes a escribir mejor, pero contenía algunas tomas de partido de carácter epistemológico. Quise dejar muy claro, por ejemplo, que el saber se despliega de distinto modo según el género que se practica. El modo de contar las cosas es determinante y no podemos prescindir del lugar donde lo hacemos, ni del público al que se orienta nuestro discurso.

Ya se que hay muchos manuales para los aprendices de escritor, pero ese libro mío sigue siendo el único en lengua española en el que se abordan las necesidades específicas de nuestra especialidad. Hay cuestiones que son imperiosas para nosotros como la gestión de las imágenes. La irrupción vertiginosa de lo digital ha dejado anticuado lo que decía allí sobre las diapositivas, por ejemplo, que han caído en desuso en los últimos años. Pero los argumentos básicos quizá sigan valiendo. Hice en sus páginas una vehemente llamada de atención acerca de una de las mayores amenazas que tiene la historia del arte a principios del siglo XXI: los derechos de reproducción. Las agencias encargadas de gestionarlos pretenden cobrar gravámenes por las ilustraciones que aparecen en las publicaciones críticas e históricas, haciendo así inviables, por razones económicas, muchos proyectos editoriales. Si no se frenan estas pretensiones, retrocederemos a la época de la ékfrasis y tendremos que escribir de arte como lo hacía Plinio el Viejo, o será preciso buscar la subvención de entidades públicas y privadas, perdiendo con ello nuestra ya precaria independencia.

Me he implicado mucho en esta batalla, participando en simposios y debates, y escribiendo artículos, defendiendo siempre el "derecho de cita visual" que reconoce (aunque con cierta ambigüedad) el artículo 32 de la vigente Ley de Propiedad Intelectual. Por eso promovimos hace unos años el llamado "Manifiesto de Soria" defendiendo la libertad de utilizar reproducciones en las publicaciones de carácter científico y didáctico. Mi largo artículo en la revista Lápiz titulado "El valor de la imagen. La crítica y la historia del arte frente a los derechos de reproducción" me convirtió en persona non grata para los responsables de VEGAP. No me arrepiento de haber contribuido a llamar la atención sobre este asunto tan importante, aunque lamento haber fracasado en mi deseo de implicar a las instituciones que más deberían comprometerse en ello: ¿Han hecho algo al respecto las universidades, las academias de bellas artes, o el CSIC? ¿No se ha comprendido, acaso, que las ciencias de la imagen necesitan libertad para poder elaborar esos discursos icónico-verbales, más inexcusables que nunca a principios del tercer milenio? Tampoco tuve éxito al intentar que se deshiciera la madeja de malentendidos que mantiene tan enredado este asunto, pues los agentes más afectados no quisieron darse por enterados de mi propuesta de que se considerasen las reproducciones atendiendo a tres factores: el grado de fidelidad al original, el nivel de autonomía de la reproducción y el destino social o uso previsible del 


Q: varia Juan Antonio Ramírez

producto resultante. Una casuística de combinaciones entre estos factores permitiría determinar cuándo habría que satisfacer derechos y cuándo no. En la réplica a mi artículo que firmó en pleno la Junta Directiva de VEGAP se desperdició la oportunidad de centrar el debate abordando las propuestas más constructivas.

En fin, quizá alguien piense que estas son meras batallas "políticas", pero yo las vivo considerándolas como vasos comunicantes de la parte científica de nuestra disciplina. Lo mismo digo respecto a la elaboración de algunos textos escolares. A finales de los años setenta redacté la tercera parte (dedicada a los siglos XIX y XX) del manual de historia del arte para el COU que publicó la Editorial Anaya: los alumnos no solían llegar a ese final del libro, pero sí lo hicieron muchos profesores, de modo que la visión sintética del arte contemporáneo que ofrecimos allí se convirtió en la más divulgada, quizá, entre las que circularon en la España de los años ochenta y noventa. Por primera vez en ese tipo de publicaciones incluimos dentro del canon a cosas como el cómic, la fotografía o el cine. En el año 2000, cuando ya estaba descatalogado el libro de Anaya, volvimos a hacer algo parecido, repensando los asuntos de nuevo, para la Historia del Arte del nuevo bachillerato de la Editorial SM. Entre ambos trabajos pudimos llevar a cabo otras tareas, como la dirección de la Biblioteca Básica de Arte de Anaya, para un público juvenil (en la que nunca salieron los tomos más contemporáneos, por culpa de los sempiternos "derechos de reproducción"); sí se culminó del todo el manual universitario, en cuatro tomos, para Alianza Editorial, para el que recabé la participación de treinta y dos reputados especialistas de diferentes universidades españolas.

Este último proyecto quiso atender a un doble propósito: ofrecer un instrumento útil, en primer lugar, para los estudiantes de las nuevas carreras de historia del arte; pero también intentábamos crear lazos científicos, reforzar la sensación de que se pertenecía a una comunidad intelectual. Nos pareció que la nueva visión estándar de la disciplina no debía ser obra de una sola persona sino de un grupo amplio que pudiera representar a la historia del arte en España, tal como esta disciplina había llegado a configurarse a finales del siglo XX.

Mi compromiso creciente con el arte más actual se ha manifestado mediante el examen en un contexto histórico de la obra de algunos creadores, y también describiendo críticamente el sistema del arte. Así es como he intentado cumplir con lo que me parece que son las dos vocaciones más persistentes de mi trayectoria intelectual: el disfrute (la comprensión) de las obras de arte propiamente dichas, y su desvelamiento ideológico. Esto último estaba claro en Ecosistema y explosión de las artes, que ya hemos comentado, donde sí hubo un deseo claro de servirme del humor (o la sátira) para mostrar el universo del arte con una aparente neutralidad entomológica, mientras insinuaba, a la vez, un cierto distanciamiento crítico respecto a lo descrito. ¿Era aquella ironía un síntoma de mi desapego del orden global que se había impuesto apoteósicamente después de 1989? Parece claro que mis últimos libros, dedicados a examinar y a valorar las obras de numerosos artistas "contemporáneos", contienen también una respuesta implícita a la tentativa de domesticar la 
Q Varia Los poderes de la imagen: para una iconología social...

experiencia artística y de enajenarla en beneficio exclusivo de los grupos sociales privilegiados y de los intereses de las grandes corporaciones.

Corpus solus. Para un mapa del cuerpo en el arte contemporáneo contiene veinte capítulos, de extensión y valor variable, dedicados a explorar distintas concepciones artísticas del cuerpo humano. Algunos de ellos me resultaron especialmente satisfactorios, como el que dediqué a las lágrimas en Picasso, mostrando las conexiones (escondidas hasta entonces) entre la fuente de mercurio Almadén de Calder, y el Guernica. Pero este libro es, básicamente, la crónica de un fracaso: yo quise dejar muy claro que mi "mapa" no podía ser más que fragmentario, y que cada capítulo del libro debía concebirse, casi, como una especie de instalación independiente, al estilo de las que había descrito Raymond Roussel en su inquietante novela Locus solus, pero no me resultó fácil asumir la imposibilidad de trazar un panorama completo del tema. El historiador que hay en mí se sintió desasosegado al tener que aceptar el comportamiento de mi otro yo, el crítico, que es inexorablemente (como ya lo dijera Baudelaire) político, parcial y apasionado. Anécdota curiosa: un colega que también es sacerdote católico me reprochó una vez el error gramatical del título de este libro sin reparar en que yo no quería aprobar un examen de latín sino evocar, de modo preciso (lo dije en le prólogo), la mencionada obra de Roussel.

Su pendant asimétrico (se ve que he tenido una tendencia a concebir los libros en parejas) fue Edificios-cuerpo, una conferencia que había impartido en un ciclo promovido por los Amigos de ARCO, y que puse por escrito durante mi estancia en el Centre Canadien d'Architecture de Montreal durante el segundo semestre de año 2001-2. Es un gran tema para un libro muy pequeño, y se nota mucho en él la presencia de algunos de mis viejos fantasmas: el Templo, los órdenes arquitectónicos, los delirios surrealistas, etc. Lo redacté pensando en una colección nueva de libros de arte y cultura visual: Azul Mínima, de Ediciones Siruela, concebida con Jacobo Stuart pero puesta en marcha ya por la nueva directora de la editorial, Ofelia Grande de Andrés. Estoy particularmente satisfecho con la dirección de esta serie al poder otorgarme a mí mismo (y a los demás) el regalo intelectual de cada uno de sus títulos. Esto es muy distinto de la oscura labor asesora para otras editoriales, importante, ciertamente, pero más ingrata, en todos los sentidos.

Muchas de mis preocupaciones anteriores confluyeron, finalmente, en la dirección de un equipo de investigación con el que elaboramos el libro Escultecturas margivagantes. La arquitectura fantástica en España. Su origen remoto puede estar en mi antiguo interés por las arquitecturas soñadas y extrañas, pero pronto adquirió el tema otras implicaciones: queríamos descubrir y valorar a los creadores espontáneos de arquitecturas desperdigados por el territorio español. Eran semianalfabetos, casi siempre, trabajaban al margen del sistema del arte, y aparecían ante nosotros como un excelente material para reflexionar sobre los orígenes antropológicos de la creación. Su presencia repentina en el seno de la alta cultura tenía un indudable valor provocador, como lo prueba el pacto de silencio que el mundo del arte contemporáneo parece haber sellado en torno a este fenómeno. Este libro tiene para mí, además, 


Q: varia Juan Antonio Ramírez

un notable valor sentimental, pues trabajé muy duramente en la edición de sus textos durante la convalecencia de una penosa intervención quirúrgica. Me quedé sordo del oído derecho y con una fastidiosa parálisis facial que ha dejado algunas secuelas permanentes. En aquellas condiciones yo me sentía muy solidario con aquellos creadores aislados e incomprendidos, que habían consagrado sus vidas a la realización solipsista de una obra personal, inútil, sin destino social aparente. El arte por el arte, al fin. Un último refugio de la utopía. La verdad es que todos los humanos somos creadores, artistas no reconocidos, y esos herederos del cartero Cheval son nuestros parientes espirituales, espejos hipotéticos de lo que podríamos ser.

Acabaré diciendo algo de mi último libro, terminado y entregado a la editorial, pero no publicado todavía en estos momentos. Se titula El objeto y el aura. (Des)orden visual del arte moderno. Me parece que implica otro cambio de tercio, pues me ocupo de un tema olvidado en los debates actuales sobre el arte contemporáneo como es el de si hay en toda la modernidad un "orden visual" distinto del que se inventó en el renacimiento y si este modo de visión posee una cierta coherencia interna. Abordo la cuestión desde seis atalayas analíticas: el punto de vista (que habría pasado de la monofocalidad del quattrocento a la visión panóptica de la modernidad), el movimiento (con la evolución desde el movimiento ilusorio al movimiento real), el primitivismo (con la puesta en cuestión de los modelos de la tradición clásica), el objeto (que se afirma como tal abandonando su estatuto subsidiario como asunto de representaciones ilusorias), el suelo como territorio privilegiado de la creación (muy importante desde la segunda mitad del siglo $\mathrm{XX}$ ) y, finalmente, el aura y la multiplicación de las imágenes (reevaluando desde otra perspectiva el término popularizado por Walter Benjamin). Quizá sea una obra demasiado ambiciosa en sus planteamientos, con la pretensión de resolver los asuntos teóricos examinando una multitud de creaciones, desde el renacimiento hasta el momento actual. Pero no es otra historia del arte contemporáneo sino un ensayo interpretativo que se plantea los "modos de visión" como fenómenos de tiempo largo (me apropio una vez más del concepto de Braudel). Sí debo decir que he sentido al escribir este libro un notable desasosiego y malignas tentaciones de abandonarlo inconcluso. Supongo que estoy en ese momento peligroso de la vida en el que podemos confundir las dudas respecto al futuro personal con la aceptación nihilista del fin de la historia. He hecho, pues, un gran ejercicio de voluntad al terminarlo. Es una manera de afirmar que la vida sigue y que la historia no se detiene. El tiempo dirá si se ha tratado de otro acto fallido.

De todos modos, como resumen de esta rendición de cuentas (y por cuya extensión os pido disculpas), sólo puedo presentar la conclusión de que no hay conclusión. Lo que ya hemos hecho no nos pertenece. Son los otros quienes deben decidir si les sirve, y hasta qué punto, lo que hemos intentado ofrecer. Muchas gracias por vuestra atención. 
Q Varia Los poderes de la imagen: para una iconología social...

\title{
APÉNDICE 1
}

\author{
Libros "académicos" de Juan Antonio Ramirez, brevemente \\ COMENTADOS.
}

-Historia y estética de la historieta española (1939-1970). (Resumen de la tesis doctoral leída en la Facultad de Filosofía y Letras de la Universidad Complutense de Madrid). Salamanca 1975. 36 págs.

Este folleto es un índice detallado de la tesis doctoral, tal como fue presentada. Algunos apartados están comentados con brevedad.

-El comic femenino en España. Arte sub y anulación. Edicusa, Madrid 1975. 254 págs. ill. (Premio de ensayo "Ciudad de Barcelona", 1975).

Publicado unos meses antes de la muerte del general Franco. Es un trabajo pionero de los "estudios de género" en los ambientes académicos de la historia del arte en España. Se hace ahí un estudio de los tebeos destinados a las chicas españolas en el periodo comprendido entre el final de la guerra civil y los primeros años setenta. Fue una oportunidad para desplegar una metodología sociológica en la que las consideraciones formales o lingüísticas tendían a desvelar la fuerte carga ideológica de aquellos productos "artísticos". El tono irónico del relato no oculta la voluntad de abordar el estudio de los tebeos con rigor conceptual, utilizando instrumentos teóricos procedentes del estructuralismo y del marxismo. Una anécdota: en la portada figura el nombre de "José Antonio" Ramírez, en vez de "Juan Antonio", una errata explicable por la omnipresencia en la España franquista de José Antonio Primo de Rivera, el fundador de la Falange Española.

-La historieta cómica de postguerra. Edicusa, Madrid 1975. 336 págs. ill.

Este libro fue, como el anterior, una derivación de la tesis doctoral, defendida en la UCM el mismo año de 1975. El estudio de los tebeos humorísticos en la España de la dictadura (hasta los primeros años setenta) se abordó utilizando una metodología sociológica y lingüística, con abundantes conceptos estructuralistas. El análisis formal de las distintas escuelas gráficas se combinaba con el de los patrones narrativos, siguiendo parámetros teóricos inspirados en Vladimir Propp y en Levi Strauss, entre otros.

-Medios de masas e historia del arte. Ed. Cátedra, Madrid 1976. 322 págs. ill. (Varias reediciones ulteriores).

Encargado por Antonio Bonet Correa para las colecciones de arte de Ediciones Cátedra, que se acababan de crear, fue redactado en un verano reutilizando, en parte, algunos materiales inéditos empleados por su autor en la tesis doctoral. Abordaba de frente el problema de la multiplicación de las imágenes en el mundo contemporáneo (se acuñó entonces el término "densificación iconográfica"), examinaba los supuestos lingüísticos de los medios icónicos (fotografía, cartel, cómic, cine y televisión), y propugnaba una renovación de la historia del arte que permitiera incluir también en su seno el examen de estos nuevos medios. Este libro se anticipó en unos 15 ó 20 años a los debates anglosajones sobre la "cultura visual" frente a la historia del 
Q: varia Juan Antonio Ramírez

arte, un asunto especialmente candente en todo el mundo a principios del siglo XXI.

-El perfil de una utopía: la catedral nueva de Orihuela. Departamento de Historia del Arte de la Universidad Complutense y Caja de Ahorros de Alicante y Murcia, Madrid 1978. 103 págs. ill.

Un estudio de archivo sobre arte, urbanismo y economía. Se examinaban las razones por las que no se ejecutó un proyecto para levantar una gran catedral en Orihuela (Alicante), en la segunda mitad del siglo XVIII. Las causas del fracaso no fueron ya económicas, pues se demostraba la buena salud de las finanzas del cabildo catedralicio, sino que obedecían a razones urbanísticas y a la aparición de una nueva mentalidad ilustrada que no veía con buenos ojos los dispendios en actividades "inútiles" o meramente suntuarias.

-Historia del Arte (con J. M. de Azcárate y A. E. Pérez Sánchez). Ed. Anaya, Madrid 1978. 1024 pág. ill. (Varias reimpresiones ulteriores). Nueva edición corregida, ampliada y rediseñada en 1995 (678 págs. ill.).

Manual concebido para el antiguo Curso de Orientación Universitaria. Yo redacté la tercera parte, dedicada al arte contemporáneo. Fue un libro muy utilizado por numerosos alumnos y profesores en toda España hasta que la editorial decidió descatalogarlo en torno al año 2002. Se incluyeron apartados dedicados al cine, la fotografía, carteles y cómics, de modo que quizá fuera la primera historia general del arte que incorporaba los principales episodios de la "cultura visual" contemporánea.

-Cinco lecciones sobre arquitectura y utopía. Universidad de Málaga, 1981. 270 págs. ill. (Reeditado con importantes ampliaciones en Edificios y sueños y en Construcciones ilusorias).

Las cinco primeras lecciones de un curso de doctorado fueron publicadas provisionalmente en esta edición restringida, para usos escolar, de 500 ejemplares. Todas esas clases (más otras cinco que se redactaron más tarde) fueron recogidas después en los libros Construcciones ilusorias y Edificios y sueños.

-Construcciones ilusorias. Arquitecturas descritas, arquitecturas pintadas. Alianza Editorial, Madrid 1983. 267 págs. ill. (Reedición en 1988).

Al acabar la tesis doctoral me orienté hacia el estudio de las fantasías y utopías arquitectónicas. Fruto de esta preocupación son varios libros relacionados entre sí. Se abordaban en éste las relaciones entre los textos (la teoría arquitectónica, pero también las obras meramente literarias y religiosas) y los edificios, tal como éstos han aparecido representados en la pintura y en la ilustración gráfica. Acuñé entonces el concepto de "iconografía del lugar", especialmente pertinente en el ensayo más largo del libro, dedicado a "El templo de Jerusalén en la pintura antigua". En otros capítulos se habla de la ciudad ideal y de los avatares iconográficos de las siete maravillas del mundo antiguo, de la arquitectura en la pintura del renacimiento, y de la prospectiva-ciencia ficción.

-Edificios y sueños. (Ensayos sobre arquitectura y utopía). Universidades de Málaga y Salamanca, Málaga 1983. 416 págs. ill. (Nueva edición en Editorial Nerea, Madrid 1991. 336 págsp. III).

Los ensayos recogidos en este libro abordan asuntos como el de ciertos edi- 
Q: varia $\quad$ Los poderes de la imagen: para una iconología social...

ficios medievales de planta centralizada en relación con el Templo de Salomón, el sistema de los órdenes en el renacimiento y el barroco, el estudio iconológico pormenorizado de la iglesia de San Ivo alla Sapienza de Roma, un análisis de la arquitectura en los cómics y en el cine (germen del libro La arquitectura en el cine), y las relaciones entre el surrealismo y la arquitectura.

-Oxidos mezclados (América, fragmentos epidérmicos). Ediciones Libertarias, Madrid 1985. 158 pág. (Finalista en el "Premio Anagrama de Ensayo", 1985).

Ensayos de carácter crítico y literario, con algunos poemas y cuentos. El libro fue escrito en Nueva York durante el curso 1982-83, mientras realizaba las investigaciones que desembocaron en La arquitectura en el cine.

-La arquitectura en el cine. Hollywood, la Edad de Oro. Ed. Hermann Blume, Madrid 1986. 349 págs. ill. (Finalista en el Premio Nacional de Ensayo otorgado por el Ministerio de Cultura; Premio "Film Historia 87"). Segunda edición: Alianza Editorial, Madrid 1993. Edición norteamericana: Architecture for the Screen. Mc Farland, Jefferson 2004. Traducción de John F. Moffitt).

La arquitectura visualizada en las películas del cine clásico fue diseñada y construida (o pintada) en Hollywood antes de ser filmada y proyectada en las pantallas de todo el mundo. En los seis primeros capítulos del libro se describen los procedimientos artísticos de los estudios y se examina la aportación de los principales artistas. La segunda parte está dedicada a los distintos estilos arquitectónicos recreados por los "directores artísticos". Este libro tiene como telón de fondo el debate entre el eclecticismo y la modernidad arquitectónica a lo largo de la primera mitad del siglo XX. El triunfo final de este "estilo" geométrico y desornamentado se produjo gracias a algunas películas sofisticadas que presentaban a personajes positivos en entornos arquitectónicos derivados de la vanguardia. Se trata, pues, de una obra que se inserta por igual en la historia del cine y en la historia de la arquitectura.

-El estilo del relax. N-340, Málaga, h. 1953-1965. (Sobre una idea de Diego Santos con fotografías de Carlos Canal). Colegio de Arquitectos de Málaga, 1987. 118 págs. ill.

La arquitectura "surrealizante" de los años cincuenta-sesenta en la Costa del Sol, tal como fue reconocida (y recreada) por el artista Diego Santos, fotografiada por Carlos Canal y examinada por mí. Este libro fue el catálogo de una exposición presentada en las salas del Colegio de Arquitectos de Málaga.

-Arte prehistórico y primitivo. Biblioteca Básica de Arte. Ed. Anaya, Madrid 1989. 96 págs. ill. Ed. italiana: Arte preistorica e primitiva. Fenice 2000, Milano 1994.

Como director de la Biblioteca Básica de la Editorial Anaya escribí este tomo para crear un modelo o estructura que pudiera ser seguido por los otros autores de la serie. La novedad mayor estribaba en presentar siempre en cada página o doble página una unidad completa de sentido, gráfica y literaria. Se explicaba el arte prehistórico y el de los pueblos sin escritura en estrecha relación con los desarrollos del arte contemporáneo. El tono era divulgativo, dirigido a un público presumiblemente juvenil.

-El Templo de Salomón según Juan Bautista Villalpando y El Templo de 


Q: varia Juan Antonio Ramirez

Salomón según Jerónimo de Prado. Acompaña a estos dos volúmenes, editados por J. A. Ramírez, un tercer volumen de estudios, dirigido por el mismo autor: Dios, arquitecto (con contribuciones de J. A. Ramírez, R. Taylor, A. Corboz, R. J. van Pelt y A. Martínez Ripoll). Ediciones Siruela, Madrid 1991. 549 pp. ill. (vol. I); 127 págs. ill. (vol. II); 364 págs. ill. (vol. III). Segunda edición de Dios, arquitecto: 1994.

La monumental reconstrucción literaria y visual del Templo de Salomón emprendida por los jesuitas Jerónimo de Prado y Juan Bautista Villalpando (este último, discípulo de Juan de Herrera), publicada originalmente en latín en Roma a principios del siglo XVII, no había sido reeditada nunca completa. Logré culminar este ambicioso proyecto editorial, después de más de siete años de trabajo. En una caja gigante se incluye: a) La traducción al castellano del volumen segundo, más los prefacios de los otros dos (a cargo del latinista José Luis Oliver Domingo), con una reproducción facsimilar de todos los grabados de la obra. b) Una edición facsímil del manuscrito alternativo, de Jerónimo de Prado (conservado en la biblioteca de la Universidad de Harvard). c) Un volumen complementario de estudios, a cargo de un equipo internacional de expertos, seleccionado por mí. d) Un disquete con índices para manejar la obra con mayor comodidad, preparado por Cristina Gutiérrez Cortines. Esta obra recibió varios premios editoriales. Los volúmenes "a" y el "c", titulados respectivamente El Templo de Salomón y Dios, arquitecto, han sido reeditados luego separadamente en la Biblioteca Azul de Ediciones Siruela.

-El arte de las vanguardias. Biblioteca Básica de Arte. Ed. Anaya, Madrid 1991. 96 págs. ill. Segunda edición: 1998. Edición italiana: L'Arte delle Avanguardie. Fenice 2000, Milano 1993.

Librito de divulgación, con las características de la colección que exigen una correcta integración entre texto e imagen.

-Gaudí. La arquitectura como obra de arte total. Ed. Anaya, Madrid 1992. 96 pp. ill.

Monografía completa y guía para visitar las obras del gran arquitecto catalán. Pese a la naturaleza divulgativa de la colección, hay algunas aportaciones novedosas que no se encuentran en otros libros dedicados al mismo creador.

-Arte y arquitectura en la época del capitalismo triunfante. Ed. Visor, Madrid 1992. 258 págs. ill.

Se recogen aquí artículos y ensayos diversos publicados antes en periódicos y revistas culturales (El País, Liberación, Lápiz, Arquitectura Viva, etc.). El tono no es erudito sino crítico. El común denominador de todos ellos es su referencia a la problemática creativa en un momento optimista para el sistema capitalista, que vivió un triunfo apoteósico tras la caída del muro de Berlín.

-Duchamp. El amor y la muerte, incluso. Ediciones Siruela, Madrid 1993. 309 pp. ill. Segunda edición: 1994. Edición inglesa: Duchamp. Love and Death, even. Traducción de Alexander R. Tulloch. Reaktion Books, Londres 1998. 293 págs. ill.

Aunque es el fruto de varios años de investigación previa, este libro fue escrito en el Getty Center for the History of Art and the Humanities de Los Ángeles durante el curso 1991-92. Es una monografía completa sobre esta figura capital de la vanguardia 
artística. Contiene una nueva lectura de los ready-mades, un examen muy minuciosos del funcionamiento y de las fuentes visuales del Gran vidrio, y un estudio detallado, también, de Étant donnés. Las obras pictóricas del primer de Duchamp (hasta 1912) son examinadas al final, como un apéndice del libro, dando a entender así la importancia de la ruptura que supuso la invención del ready-made, a partir de 1913.

-Grupos temáticos del tebeo de aventuras en la España de la postguerra. Los mamotretos de Grafito. Serie Fotoplagias, letra V. Colectivo Nutria y Mario Ayuso Editor. Madrid 1994. 68 págs. ill. [Reproducción facsímil del artículo del mismo título publicado en dos partes en Cuadernos de Realidades Sociales, nums. 8-9, Madrid 1975 y 1976].

Edición clandestina, no controlada ni autorizada por el autor (aunque benevolentemente aceptada a posteriori) de dos artículos largos publicados en una revista especializada en los años setenta. Estos textos (como los dos primeros libros) eran, básicamente, fragmentos desgajados de la tesis doctoral.

-Ecosistema y explosión de las artes. Condiciones de la historia, segundo milenio. Ed. Anagrama, Barcelona 1994. 148 págs., ill. Edición francesa: Les usines à valeurs. Écosystème des arts et explosion de l'histoire de l'art. Éditions Jacqueline Chambon, colección "Rayon Art", Marsella 1995.

Utilizando la estrategia de las viejas cartillas escolares y de los libros de emblemas, se hace una descripción del sistema del arte hablando de los agentes que componen su "ecosistema" y de las condiciones intelectuales que permiten elaborar la historia del arte. Muchos capítulos están acompañados por ilustraciones semi-humorísticas con unos versitos alusivos a la problemática correspondiente. Se trata de un libro engañoso en su aparente simplicidad, pues su formato "infantil" esconde una carga crítica contra la confusión y la pedantería, tan abundantes en el sector artístico contemporáneo.

-Picasso. El mirón y la duplicidad. Alianza Cien, Madrid 1994. 72 págs. ill. Reedición ampliada: Picasso, biografía. El mirón y la duplicidad. Suplemento especial SUR, 25 de octubre de 2003, págs. 1-23.

Monografía pequeña pero completa sobre el genial artista malagueño, escrita ex profeso para una colección de precio fijo y mínimo, cien pesetas. Bromeé sobre ello diciendo que este librito era "el Picasso más barato del mundo".

-Arte, resquemor y pavesas errantes del 92. Lápiz, Colección "Textos [im]pertinentes", Madrid 1994. 189 págs., ill.

Primero y único título de una colección de libros que iba a sacar la revista Lápiz. Se recogen en él algunos textos críticos sobre la huella y los ecos artísticos de aquel "año de España" que fue el 1992.

-Cómo escribir sobre arte y arquitectura. Libro de estilo e introducción a los géneros de la crítica y de la historia del arte. Ediciones del Serbal, Barcelona 1996. 190 págs. ill. Segunda edición corregida y ampliada: 1999.

Esta obra se dirige preferentemente a los estudiantes de arte y de arquitectura que quieran escribir sobre sus materias. Contiene consejos y trucos profesionales para hacer artículos y críticas, libros de distinto tipo, guiones, etc. Es especialmente útil para 


Q: varia Juan Antonio Ramírez

quienes deseen elaborar tesis doctorales. La naturaleza icónico-verbal de la escritura artística es tenida muy en cuenta en las indicaciones suministradas en todo momento. -Historia del Arte. 4 vols. Alianza Editorial, Madrid 1996-1997. [Director de toda la obra, autor de los cuatro prólogos y del módulo "El arte de las vanguardias históricas" incluido en el vol. 4, dedicado a la "Época contemporánea"].

La necesidad de dotar de instrumentos didácticos fiables y actualizados a las nuevas generaciones de estudiantes universitarios me estimuló para dirigir esta obra. Participaron en ella 32 historiadores del arte españoles que redactaron otros tantos "módulos" temáticos, repartidos en cuatro volúmenes. Se trata de un manual que contiene el saber esencial (y las ilustraciones básicas) de toda la historia universal del arte.

-Historia y crítica del Arte: Fallas (y Fallos). Art History and Critique: Faults (and Failures). Kunstgeschichte und Kunstkritik: Kennen (und Können). Fundación César Manrique (Lanzarote), Colección Cuadernas, Madrid 1998, 113 págs. ill.

La versión inicial de este texto fue presentada como una ponencia-marco en el XI Congreso del CEHA celebrado en Valencia el año 1996. Se trata de una invitación a reconsiderar el papel y la función de la historia y de la crítica del arte. Los fallos (o fallas) de la vieja disciplina deben alumbrar una nueva actitud que permita considerar a la historia del arte como una disciplina paradigmática en las sociedades contemporáneas, muy condicionadas por el papel predominante de las imágenes.

- La metáfora de la colmena: de Gaudí a Le Corbusier. Ediciones Siruela, Madrid 1998, 184 pp., ill. Edición inglesa con algunas ampliaciones: The Beehive Metaphor. From Gaudí to Le Corbusier. Reaktion Books, London 2000, 174 págs. ill. Edición italiana: La metafora dell'alveare nell'architettura e nell'arte. Bruno Mondadori, Milán 2002, 166 pp. Edición rumana: Metafora stupului. De la Gaudí la Le Corbusier. Editura Meridiane, Bucarest 2003, 118 págs. Edición turca: Dost, Ankara 2007.

Mi infancia, con la presencia constante de las colmenas de mi padre apicultor, explica en parte la intuición inicial que dio origen a este libro: en los orígenes y en el primer desarrollo del Movimiento Moderno jugaron un importante papel las metáforas apícolas. Se estudian en este sentido algunos casos ejemplares como los de Gaudí, Wright, La Ruche de Montparnasse, el expresionismo alemán y Le Corbusier. Se trata de una época en la que las colmenas suscitaban todo tipo de asociaciones positivas.

-Guernica. La historia y el mito, en proceso. Electa, Madrid 1999, 63 págs. ill.

Libro de divulgación dedicado a este célebre cuadro de Picasso. Pero contiene aportaciones personales al situar a esta pintura en la órbita surrealista, y dentro de la secuencia narrativa del "Sueño y mentira de Franco". También se apunta ya, entre otras cosas, a la relación de "Guernica" con la fuente "Almadén" de A. Calder, un asunto que desarrollé luego en uno de los capítulos de Corpus Solus.

-Historia del Arte. Bachillerato 2. Con Manuel Arias, Ma Antonia García Fuentes, Beatriz del Castillo y Belén Pallol. Ediciones SM, Madrid 1999, 527 págs. ill. Segunda edición corregida: 2000. Seguido de Historia del Arte. Recursos didácticos. Con un CDROM. En colaboración con Manuel Arias, Carmen Blanco, Belen Pallol, y el equipo de 
Q: varia $\quad$ Los poderes de la imagen: para una iconología social...

SM. Ediciones SM, Madrid 2001. Varias reimpresiones en los años ulteriores.

Manual para la enseñanza de la historia del arte en el nuevo bachillerato. Yo redacté el tema primero y todos los relativos al arte del siglo XX. También soy el autor de los pequeños ensayos temáticos, correspondientes a todas las épocas de la historia del arte, que están intercalados en distintos lugares del libro.

-Latoflexia y latotomía. Tratado breve. Área de Cultura. Ayuntamiento de Málaga. Sala de Arte Moreno Villa, Málaga 2000. ill.

El año 2000 expuse en Málaga mis creaciones de latas cortadas y dobladas. Pero en vez de elaborar para la ocasión un catálogo convencional con ensayos y fotos de las obras, decidí publicar un tratado sobre el modo de ejecutar muchas de las cosas presentadas. Me inspiré para ello en los antiguos manuales de papiroflexia. La latoflexia, tal como la entiendo, es un arte mínimo, social (muchos pueden practicarlo), rápido, barato, no comercializable y ecológico (es importante la idea del reciclaje).

-Dalí: lo crudo y lo podrido. Visor-La Balsa de la Medusa, Madrid 2002, 152 págs. ill.

Se recogen en este libro tres ensayos dedicados a Salvador Dalí: en el primero de ellos se abordan cuestiones como las visiones del cuerpo y del amor que mantuvo el artista ampurdanés; el segundo está dedicado a su concepción de la arquitectura (se analizan sus distintos "clasicismos"); el tercero se ocupa de mostrar las relaciones entre el método iconológico, de gran abolengo en la historia del arte, y el paranoico-crítico elaborado por Dalí.

-Corpus solus. Para un mapa del cuerpo en el arte contemporáneo. Ediciones Siruela, Madrid 2003. 355 págs. ill.

Este libro partió de la tentativa de presentar un panorama de lo que el arte contemporáneo (desde finales del siglo XIX hasta el momento actual) ha realizado con el cuerpo humano. El resultado es un conjunto de fragmentos que podrían servir para la elaboración de un hipotético "mapa" completo del cuerpo, algo que considero realmente imposible: se trata de veinte ensayos en los que se tratan cuestiones como el cuerpo ideal, el cuerpo en movimiento, la ropa, la piel, el cuerpo desmembrado, el cuerpo transparente, los fluidos corporales (las lágrimas), el sexo, etc. Junto a estos temas generales hay capitulos dedicados a artistas concretos como David Nebreda, Orlan, Lygia Clark, Rebeca Horn, Elena del Rivero, Aganetha Dyck, Amaya Bozal, etc. El título del libro es una evocación de Locus solus de Raymond Roussel.

-Edificios-cuerpo. Cuerpo humano y arquitectura: analogías, metáforas, derivaciones. Ediciones Siruela, Madrid 2003, 104 pp., ill.

Este libro es un pendant asimétrico de Corpus solus. Trata del modo como las metáforas corporales han influido en la teoría y en la práctica arquitectónicas. Se estudian los ecos de Vitruvio desde el renacimiento en adelante y la teoría proporcional antropocéntrica, con su reemergencia en el modulor de Le Corbusier. Los edificios con forma de cuerpo (completa o parcial) reciben un tratamiento especial examinándose la obra de arquitectos o de pintores de arquitecturas, especialmente 


Q: varia Juan Antonio Ramírez

importantes en la órbita surrealista.

-Tendencias del arte, arte de tendencias a principios del siglo XXI. (Juan Antonio Ramírez y Jesús Carrillo, editores). Ediciones Cátedra, Madrid 2004, 310 págs. ill.

Este libro es el resultado de las sesiones de trabajo del seminario que dirigí en el mes de julio de 2003 por encargo de la Fundación Duques de Soria. Se recogen los textos de diez autores en los que se traza una panorámica de las tendencias y pulsiones del arte en los primeros años del siglo XXI.

-Escultecturas margivagantes. La arquitectura fantástica en España. Eciciones Siruela, Madrid 2006, 463 págs., ill. [J. A. Ramirez, director. Otros autores: G. M. Borrás, J. Díaz, F. J. Galante, J. Hernando, J. J. Lahuerta, M. M. Lozano, F. Martín, F. J. Pérez, C. Reyero, L. Rosa, F. J. San Martín, M. Seguí, M. L. Sobrino].

Consecuencia final de un proyecto de investigación colectivo financiado por el Ministerio de Educación, contiene más de sesenta ensayos sobre los principales creadores marginales del estado español. Son escultores espontáneos que trabajan como arquitectos (o viceversa) y de ahí el término que inventamos para designarlos. Próximos al art brut constituyen el último descubrimiento dentro de la escena del arte. Yo escribí el prólogo y tres ensayos monográficos, determiné la estructura de la obra y redacté las 10 introducciones de los capítulos.

\section{APÉNDICE 2}

Articulos especializados, capitulos de obras colectivas, y ENSAYOS EN CATÁLOGOS.

[Selección de algunos de los textos más relevantes que no han sido recogidos en los libros de JAR]

-"Las pintadas y sus transformaciones. Factores semánticos y expresivos del ruido visual". Comunicación XXI, num. 18, Madrid 1974, págs. 15-16, 22 y 45-46.

-"Grupos temáticos del tebeo de aventuras en la España de la postguerra. Notas para una historia iconográfica e ideológica". [Dos entregas en otros tantos números de la misma revista]. Cuadernos de Realidades Sociales, num. 8, septiembre de 1975, págs. 81-120, y num. 9, enero de 1976, págs. 87-150.

-"Estructura e ideología del tebeo de aventuras en la España de postguerra". Cuadernos de Realidades Sociales, num. 13, mayo de 1977, págs. 27-46.

-"Guarino Guarini, Fray Juan Ricci and the Complete Salomonic Order". Art History, vol. 4, num. 2, junio 1981, págs. 175-185.[Edición española: "Guarino Guarini, Fray Juan Ricci y el orden salomónico entero". Goya, num. 160, enero-febrero 1981, págs. 202-211.

-"Imágenes para un pueblo. Connotaciones, arquetipos y concordancias en la iconografía de postguerra". En el libro dirigido por A. Bonet Correa Arte del franquismo. Ed. Cátedra, Madrid 1981, págs. 225-260.

-"Catecismo breve de la postmodernidad. Notas provisionales". La luna de 
Madrid, num. 24, enero de 1986, pp. 20-22. También en el libro colectivo La polémica de la postmodernidad. Eds. Libertarias, Madrid 1986.

-"El transatlántico y la estética de la máquina en la arquitectura contemporánea". El Croquis, año V, num. 25, Madrid, julio de 1986, págs. 6-22. También en las actas del simposio El barco como metáfora visual y vehículo de transmisión de formas. CEHA, Málaga-Melilla 1985, págs. 15-57.

-"L. A. 92: Ripe rap, destrucción deconstrucción". Revista de Occidente, Núm. 145, Junio 1993, pp. 115-143. También en Tensiones del arte y la cultura en el fin de siglo, (Francisco Jarauta, editor), Arteleku, San Sebastián 1993, págs. 91-132.

-"Francesc Torres: Emblems, Allegories, Theater of Memory... / Francesc Torres: emblemas, alegorías, teatro de la memoria..." [texto en español e inglés]. En Too Late for Goya. Works by Francesc Torres. Catálogo de exposición a cargo de Marilyn Zeitlin. Arizona State University Art Museum. Tempe, Arizona 1993, págs. 24-39.

-"Duchamp: corps démultiplié, hasard objectif et action". En el catálogo de la exposición Fémininmasculin. Le sexe de l'art. Centre Georges Pompidou, Gallimard/Electa, París 1995, págs. 279-283.

-"Fragmentos y ruinas de utopía. (Textículos de La Habana)". La Balsa de la Medusa, num. 37, 1996, pp. 75-91. Edición italiana: "Frammenti e rovine di utopia. (Textículos dall'Avana)". Oz. Rivista Internazionale di Utopie, num. 3, 1995, págs. 69-81. 74-79.

-"El mito de la Dama de Elche". Historia 16, num. 251, marzo 1997, págs. 3 y

-"Camuflatge. (Ocultació. Dissimulació)". Transversal. Revista de cultura contemporània. num. 2, Lleida 1997, págs. 37-39.

-"Espiral de utopías. Kabakov: palacio (torre y faro) de los proyectos". Arquitectura Viva, num. 65, marzo-abril 1999, págs. 70-72. Edición en inglés ("Spiral of Utopias. Kabakov: Pallace (Tower and Lighthouse) of Projects") y en japonés en $A+U$. Architecture and Urbanism (Tokyo), num. 00:01 (352), enero del 2000, págs. 12-23.

-"Que cien años no es nada. La modernidad como ciclo largo y el punto de vista múltiple". En el catálogo de la exposición Confines. Miradas, discursos, figuras, en los extremos del siglo XX. Comunidad de Madrid, Consejería de Cultura, Madrid 2000, págs. 43-58.

-"Am rande des Abgrundes: künstlerische Beweggründe für sechs Arten von Umarmungen" ["Al borde del abismo: razones artísticas para seis tipos de abrazos"]. En el catálogo Picasso: Die Umarmung. Neue Nationalgalerie, Berlín 2000, págs. 4957 y 293-297. Reeditado en Picasso vuelve. Pedro Luis Gómez (coordinador). SUR, Málaga 2003, págs. 128-139.

-"Reflejos y reflexiones del medio especular. Reflections Upon the Mirror as a Medium". Exit. El espejo. Número cero, Madrid 2000, págs. 16-36.

-"Un neorrealismo pauperista. (La contra-arqueología lingüística de Rogelio López Cuenca)". "A Pauperistic Neo-realism. (The Lingüistic Counter-archaeology of Rogelio López Cuenca)". En el catálogo Rogelio López Cuenca. Obras. Diputación 
Q: varia Juan Antonio Ramírez

de Granada, Granada 2000, págs. 11-30 y 141-150.

-"Escales pintades (escales sens fi) / Escaleras pintadas (escaleras sin fin)". Más trece fichas relativas a otros tantos cuadros con escaleras: "Escalera de tramo recto"; "Escalera que surge de un muro"; "Escalera de tramos paralelos"; "Escalera de dos tramos en ángulo"; "Escalera de varios ramales"; Escalera imperial"; "Escalera samba"; "Escalera en el aire"; "Horror a la barandilla"; "Escalera aleatoria"; "Escalera de trazo curvo"; "Subir (a los cielos), descender (a los infiernos)". En el catálogo de la exposición Réquiem per l'escala/ Réquiem por la escalera. Comisario: Oscar Tusquets. Centre de Cultura Contemporània de Barcelona, 2001, págs. 17-30 y 64, 78, 88, 98, $108,124,134,144,156,166,178,194,208$. Reeditado con algunas modificaciones en Réquiem por la escalera/Réquiem for the Staircase. RqueR editorial, Barcelona 2004.

-"Nota (apasionada) sobre gestos y pasiones". En el catálogo Julio Romero de Torres. Símbolo, materia y obsesión. Fundación Provincial de Artes Plásticas Rafael Botí, Córdoba 2003, págs. 157-162.

-"Desintegración: de Babel al 11 de septiembre". Conferencia de clausura del $14^{\circ}$ Congreso del CEHA. En Correspondencia e integración de las artes. Actas del XIV Congreso Nacional de Historia del Arte. (Málaga, del 18 al 21 de septiembre de 2002). Tomo I. Ministerio de Educación, Cultura y Deportes, Málaga 2003, págs. 27-58.

-"La utopía daliniana y la basura artística". En el catálogo Dalí. Cultura de masas. Comisario Félix Fanés. Fundación Gala-Salvador Dalí, MNCARS y Fundación La Caixa, Barcelona 2004, págs. 250-253. [Con ediciones en catalán y en inglés]. Reeditado en holandés en el catálogo Alles Dalí. Film, mode, fotografie, design, reclame, schilderkunst. Museum Boijmans van Beuningen, Rótterdam 2005 [con otra edición en inglés: It's all Dalí. Film, fashion, photogrphy, design, advertising, painting]

-"Dalí: Edificios-cuerpo". En Persistence and Memory. New Critical Perspectives on Dali at the Centennial. Edited by Hank Hine, William Jeffett and Kelly Reynolds. The Salvador Dalí Museum St. Petetersburg, Florida-Bompiani, 2004, págs. 105-112.

-"Superpigmalión. El artista contemporáneo, ampliado y mejorado". En Facundo Tomás e Isabel Justo (Eds.), Pigmalión o el amor por lo creado. Anthropos y Universidad Politécnica de Valencia, Barcelona 2005, págs. 241-260.

-"El valor de la imagen. La crítica y la historia del arte frente a los derechos de reproducción". "The value of an Image. Criticism and Art History faced with the Copyright Issue”. LAPIZ. Revista Internacional de Arte. Num. 217, noviembre 2005, págs. 26-41.

-“Lichtenstein, en proceso". En el catálogo Lichtenstein en proceso. Fundación Juan March, Madrid 2005, págs. 13-23. [Versión inglesa: "Lichtenstein, in Process". págs. 94-100]. Reeditado con algunas correcciones en el catálogo Roy Lichtenstein, de principio a fin. Fundación Juan March, Madrid 2007, págs. 16-23. [Con edición en inglés]. Edición francesa:“Lichtentein, l'art en mouvement". En el catálogo Roy Lichtenstein. Évolution. Pinacothèque de Paris, Paris 2007, págs. 16-23.

-"De la ruina a la destrucción arquitectónica (Para una iconografía del caos)". En La multiculturalidad en las artes y en la arquitectura. Actas del XVI congreso del CEHA. Ponencia-marco de la Mesa II: Arte y conflictos bélicos en la Historia: de la 
Q Varia Los poderes de la imagen: para una iconología social...

aldea al mundo global. Las Palmas de Gran Canaria, 2006, págs. 525-553.

-"El Bosco en la vanguardia". En AA VV, El Museo del Prado y el arte contemporáneo. La influencia de los grandes maestros del pasado en el arte de vanguardia. Fundación Amigos del Museo del Prado-Galaxia Guttenberg-Círculo de Lectores, Barcelona 2007, págs. 37-68.

-"Etapas, escenarios y contextos: José Guerrero, por estratos". En José Guerrero. Catálogo razonado. Volumen 1, 1931-1969. Centro José GuerreroTelefónica, Granada 2007, págs. 68-97.

-"Aura: el regreso". En In sapientia libertas. Escritos en homenaje al profesor Alfonso E. Pérez Sánchez. Museo Nacional del Prado / Fundación Focus -Abengoa, Madrid 2007, págs. 815-833. 